-

\title{
MLD システム表現に基づく群集挙動のモデリング*
}

幸加木 徹 ${ }^{\dagger}$. 児島 晃

\author{
A Modeling of Pedestrian Flow Based on MLD System \\ Approach*
}

Toru KoukAKI ${ }^{\dagger}$ and Akira KoJImA ${ }^{\ddagger}$

\begin{abstract}
A simulation model of pedestrian flow is introduced based on Mixed Logical Dynamical (MLD) system approach. Typical phenomena in the evacuation flow are generated with the proposed model and, further, it is verified that improved outflows can be reached by obstacles placed asymmetrically in front of the exits. The feature of the congestion in the evacuation is also discussed in terms of the flow coefficient.
\end{abstract}

1. はじめに

人間の行動特徵を把握し群集挙動を予測することは， 都市計画や建築設計の安全性を評価することに役立ち， 災害時，避難行動を円滑に誘導するための手段として有 効であると考えられている $[1-5]$. とくにパニック時の行 動を実証することは危険を伴うと考えられるので , 歩行 者の挙動を再現できる精巧なシミュレーションモデルが 求められている $[5]$.

現在まで, さまざまなアプローチにより群集挙動のシ ミュレーションが行われている. 文献 [5-8] で提案され たモデルは，すべての歩行者の間や障害物，壁などとの 作用に仮想的なポテンシャルを設け群集挙動を記述した ものであり，さまざまな斥力を定めシミュレーションが 行われている. このモデルは, ロボティクス分野におけ る人工ポテンシャル法 $[9,10]$ と共通した接近法であり， 複杂倠なフィールドにおいてはさまざまな⿻斤丶を適切に定 め, 停留点を解消したうえで群集挙動を表現する必要が ある. とくに文献 [7] では通路での歩行者の流量の変化 が調べられ，障害物を出口正面から非対称に配置すると

\footnotetext{
* 原稿受付 2009 年 10 月 9 日

†本田技研工業 (株) Honda Motor Co., Ltd.; Minamiaoyama 2-1-1, Minato-ku, Tokyo 107-8556, JAPAN

‡首都大学東京 大学院システムデザイン研究科 Graduate School of System Design, Tokyo Metropolitan University; Asahigaoka 6-6, Hino-city, Tokyo 191-0065, JAPAN

Key Words: model predictive control, mixed logical dynamical system, pedestrian flow.
}

退出時間が短縮されることが示されている. としてこれ らの結果から，将来，駅やスタジアムなどの公共施設に おいて, 群集の流れがよくなるような設計の改善案につ いてまとめられている [5]. また, 文献 $[11,12]$ で提案さ れたモデルは, 歩行者, 障害物をセルオートマトンで扱 い，群集挙動を状態遷移により表したものであり，広域 でのシミュレーションを容易に扱うことができる. 光し て文献 [11] では障害物の配置による効果 [7] を提案モデ ルで再現し，モデルの妥当性を評価している. しかしな がら，1)出口付近に歩行者が集中する現象を表現するた めには, あらかじめ状態遷移を適切に定め調整する必要 があること，2) 出口の幅などシミュレーションの設定が セルの大きさにより制限されることが報告され，さらに 考察が進められている [12].

一方, システム制御分野ではハイブリッドシステム表 現と炎の制御法への応用に関する研究が進められ, 対象 のモード遷移を含めた記述能力の高い表現が開発されて きた $[13,14]$. そして，これらの手法は制御対象のダイナ ミクスとモードを同時に扱うことを可能にするため，人 間の動特性を考慮した経路計画や複杂倠な行動のモードを 的確に表現できる可能性がある.

本研究では, ハイブリッドシステムの記述法のひとつ である Mixed Logical Dynamical System (MLD シス テム) 表現を用いて群集挙動のモデリングを行う [13]. 乥 して，建築分野で明らかにされてきた現象がMLD シス テム表現に基づいて再現できることを示す. 群集挙動を 表現するためには, 歩行者一人一人の基本的な経路計画 をモデル化し，障害物に対応する経路計画の変更などの 
論理を整理する必要がある.さらに, 群集内では歩行者 の複雑な運動を他の歩行者との相互作用によって表現す ることが必要である. 乥こで本考察では，1) 目標点に至 る歩行行動，2) 障害物の回避，3) 他の歩行者との相互作 用，をMLD システム表現より表し，歩行行動を歩行者 のモデルに印加する外力により表現することを考える. 乥して, 各歩行者に印加される外力をモデル予測制御に より求めて, 群集の自律的な動きを表現する.

本手法を，文献 [5-8] と対比させた場合，1) 障害物や 壁などの配置，他の歩行者との相互作用が容易に定義で きること，2) 経路計画にモデル予測制御を用いるため， 複雑な経路計画に基づく挙動が表現できること，が特徵 にあげられる. また, 文献 $[11,12]$ と比較した場合，各歩 行者の座標，壁や出口の大きさを連続量で扱うことが可 能であり，さまざまな設定における挙動が同一のモデル により調べられると考えられる.

以下では, はじめに MLD システム表現を用いた群集 挙動のモデリングについてまとめ, 基本的なアルゴリズ ムを整理する ( 2 節).つぎに提案した群集モデルに基づ き, 部屋からの避難行動のシミュレーションを行い, 流 動係数 [18] との関係から, 退出時の障害物配置による効 果を検討する $(3$ 節 $)$.

\section{2. 群集挙動のモデリング}

群集挙動のモデリングのため , はじめに歩行者の基本 モデルと経路計画に関する基本的なアルゴリズムを整理 する. 歩行者は質点系の運動により表し，また歩行者の 自律的な行動は，離散時間モデル予測制御により求めら れた制御入力から表現することにする.

\section{1 歩行者の基本モデル}

人間の歩行行動に関する特性を質点 $m[\mathrm{~kg}]$ の運動とし， 加速，減速の緩慢さを抵抗係数 $\mu[\mathrm{Ns} / \mathrm{m}]$ で表現する. $x$ 方向, $y$ 方向の変位を $x[\mathrm{~m}], y[\mathrm{~m}]$, 歩行速度を $v_{x}[\mathrm{~m} / \mathrm{s}]$, $v_{y}[\mathrm{~m} / \mathrm{s}]$, 弚れ方向に働く力を $f_{x}[\mathrm{~N}], f_{y}[\mathrm{~N}]$ とす ると, 対応する運動方程式は，

$$
\begin{aligned}
m \ddot{x}+\mu \dot{x} & =f_{x} \\
m \ddot{y}+\mu \dot{y} & =f_{y}
\end{aligned}
$$

となり, 状態方程式はつぎのように求められる.

$$
\begin{aligned}
\dot{s} & =A_{c} s+B_{c} u \\
s & =\left[x, y, v_{x}, v_{y}\right]^{\mathrm{T}}, \quad u=\left[f_{x}, f_{y}\right]^{\mathrm{T}} \\
A_{c} & =\left[\begin{array}{cccc}
0 & 0 & 1 & 0 \\
0 & 0 & 0 & 1 \\
0 & 0 & -\frac{\mu}{m} & 0 \\
0 & 0 & 0 & -\frac{\mu}{m}
\end{array}\right], \quad B_{c}=\left[\begin{array}{cc}
0 & 0 \\
0 & 0 \\
\frac{1}{m} & 0 \\
0 & \frac{1}{m}
\end{array}\right]
\end{aligned}
$$

ぞして，サンプル時間 $h[\mathrm{~s}]$ て離散化すると，つぎの状態 方程式が得られる.

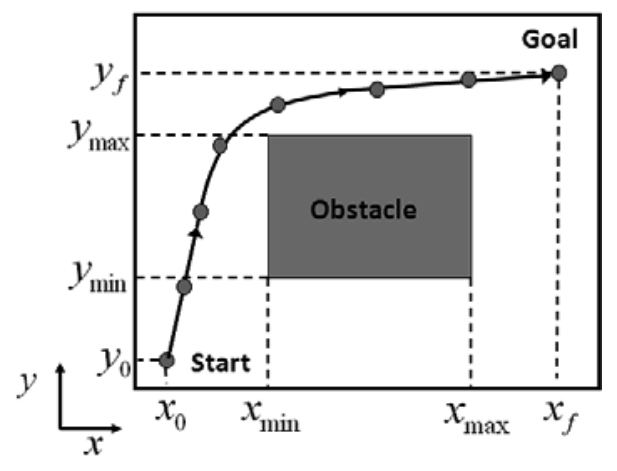

Fig. 1 Basic problem

$$
\begin{aligned}
s(t+1) & =A_{d} s(t)+B_{d} u(t), \quad t=0,1,2, \ldots \\
s(t) & =\left[x(t), y(t), v_{x}(t), v_{y}(t)\right]^{\mathrm{T}} \\
u(t) & =\left[f_{x}(t), f_{y}(t)\right]^{\mathrm{T}} \\
A_{d} & =e^{A_{c} h}, \quad B_{d}=\int_{0}^{h} e^{A_{c} \tau} d \tau B_{c}
\end{aligned}
$$

ここでは文献 $[20,21]$ などの検討に基づき， $m=60[\mathrm{~kg}]$ ， $\mu=20[\mathrm{Ns} / \mathrm{m}]$ とした ${ }^{1}$. また, 歩行者の速度の上限を $v_{\text {max }}[\mathrm{m} / \mathrm{s}]$ と表し，歩行行動を考える. 速度制約は

$$
0 \leq \sqrt{v_{x}^{2}+v_{y}^{2}} \leq v_{\max }
$$

を線形不等式により 16 角形近似したものを用い, 次式 のように表すことにする.

$$
\left(v_{x}, v_{y}\right) \in D\left(v_{\max }\right)
$$

つぎに，Fig. 1 の例を用いて，歩行者か障害物を回避 しながら目標点まで歩行する基本的なアルゴリズムを説 明する. 時刻 $t$ における状態 $s$, 入力 $u$ を

$$
\begin{aligned}
s(t \mid t) & =\left[x(t \mid t), y(t \mid t), v_{x}(t \mid t), v_{y}(t \mid t)\right]^{\mathrm{T}} \\
u(t \mid t) & =\left[f_{x}(t \mid t), f_{y}(t \mid t)\right]^{\mathrm{T}}
\end{aligned}
$$

と表し , 入力列を

$$
U:=\{u(t \mid t), u(t+1 \mid t), \ldots, u(t+N-1 \mid t)\}
$$

とすると, 状態の予測値

$$
\begin{aligned}
& s(t+k \mid t)= \\
& {\left[x(t+k \mid t), y(t+k \mid t), v_{x}(t+k \mid t), v_{y}(t+k \mid t)\right]^{\mathrm{T}},} \\
& k=1,2, \ldots, N
\end{aligned}
$$

は，(5) 式から求められる. 㫕して，Fig. 1 の障害物

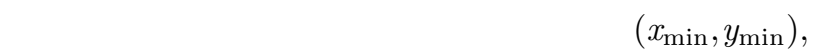
$\left(x_{\max }, y_{\max }\right)$ と与えると，回避しながら歩行する条件は，

${ }^{1}$ 文献 $[20,21]$ において, 実際に対向させた歩行者の軌跡 とシミュレーション結果を対比させ $\mu$ の值か調べられ ている. また質量 $m$ の值には樣々な分散が考えられ るが, $50-70[\mathrm{~kg}]$ の間て変化させても, ほとんど経路計 画に影響がないため，本モデルでは一定值とする. 
各時刻でつぎのように表される.

$$
\begin{aligned}
x(t+k \mid t) & \leq x_{\min }+M \delta_{1}(t+k \mid t) \\
-x(t+k \mid t) & \leq-x_{\max }+M \delta_{2}(t+k \mid t) \\
y(t+k \mid t) & \leq y_{\min }+M \delta_{3}(t+k \mid t) \\
-y(t+k \mid t) & \leq-y_{\max }+M \delta_{4}(t+k \mid t) \\
& \sum_{l=1}^{4} \delta_{l}(t+k \mid t) \leq 3
\end{aligned}
$$

ここで, $\delta_{1}(t+k \mid t), \delta_{2}(t+k \mid t), \delta_{3}(t+k \mid t), \delta_{4}(t+k \mid t)$ は 状態 (5) に対応して導入した 0-1 変数であり， $M$ は障 害物の横幅 $\left(x_{\max }-x_{\min }\right)$, 縦幅 $\left(y_{\max }-y_{\min }\right)$ に比べて 十分大きな正数である. また (13e) 式により，離散変数 には, 少なくともひとつが 0 になる制約が設けられてい る.したがって，たとえば $\delta_{1}(t+k \mid t)=0$ の場合，(13a) 式が $x(t+k \mid t) \leq x_{\min }$ となり，Fig. 1 における障害物の 左側が歩行可能領域となる. 同樣にして, $\delta_{2}, \delta_{3}, \delta_{4}$ が 0 の場合を合わせて考えると，障害物の周囲が歩行可能領 域として表される.

つぎに目標点を $s_{f}=\left[x_{f}, y_{f}, 0,0\right]^{\mathrm{T}}$ と与え，(5) 式 に対する評価関数を

$$
\begin{array}{r}
J=\sum_{l=1}^{N-1}\left\{\left(s(t+k \mid t)-s_{f}\right)^{\mathrm{T}} Q\left(s(t+k \mid t)-s_{f}\right)\right. \\
\left.+u(t+k \mid t)^{\mathrm{T}} R u(t+k \mid t)\right\}, \\
Q \geq 0, R>0
\end{array}
$$

と定めると, 歩行者が経路を決定する問題は, 以下の混 合整数 2 次計画問題にまとめられる.

$$
\min _{U} J, U:=\{u(t \mid t), u(t+1 \mid t), \ldots, u(t+N-1 \mid t)\}
$$

$$
\text { subj.to }\left[\begin{array}{l}
\text { 状態方程式 }(5) \\
\text { 位置 ・速度の制約 }(8), \quad k=0, \ldots, N-1 \\
\text { 衝突回避条件 }(13)
\end{array}\right.
$$

すなわち, 最適化問題 (15) を receding horizon で解く ことにより，空間内の障害物や他の歩行者を回避し，目 的地に到達する各歩行者の歩行行動が表現できる.

また，歩行者自身の大きさ (占有領域) を考慮するた めに , 周囲の障害物の制約を Fig. 2 のように定めること にする. 注目している歩行者の大きさが $D[\mathrm{~m}]$ 四方であ るとき，他の歩行者，障害物の占有領域は Fig. 2 のよう に変更して表すことにする. このような変更により，歩 行者の経路計画問題は, 歩行者を質点とみなした基本問 題 (14),(15) に帰着される. これらの手法は文献 [20,21] や自動車の衝突回避問題 [15]で扱われてきた.

\section{2 群集内の相互作用}

2.1 節の考察により，障害物を回避する基本的な歩行 行動がMLD システムのモデル予測制御により表される

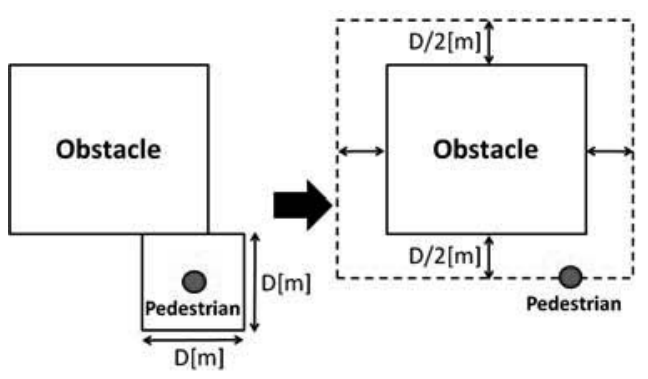

Fig. 2 Equivalent occupied region

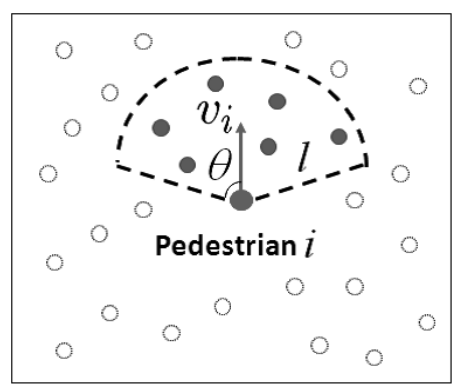

Fig. 3 Recognition region of pedestrian

ことが確認された. 本節では, さらに建築分野で明らか にされた群集内での歩行行動の特徵 $[16,17]$ を反映させ， 群集挙動のモデリングに必要な条件について整理する. 各歩行者の経路計画は群集内で最も影響を受ける他の歩 行者の位置関係により定まり, また速度の最大值は群集 内の歩行者の密度により定まることが知られている [2]. 光こで文献 [2] に基づき，つぎのような (1) 歩行速度の 評価, (2) 停止・回避行動のモード, (3) 追従行動のモ一 ド，を導入する.

(1) 歩行速度の評価

歩行者は歩行空間の部分的な情報から周囲の歩行 者を認識し, 歩行速度とモードを選択すると考えられ る $[2,16,17]$. 本論文では歩行者 $i$ の認識距離を $l=3.0[\mathrm{~m}]$ ， 認識角を $\theta=\pi / 3[\mathrm{rad}]$ とし, 進行方向に合わせて認識領 域を Fig. 3 のように表す.

乥して, 認識領域 (Fig. 3) の歩行者の数に応じて, (7) 式の $v_{\max }$ の值を

$$
v_{\max }=0.5 \cdot v_{\max }^{0}+0.5 \cdot \frac{1}{1+n} v_{\max }^{0}
$$

と変化させることにする. ここでの $v_{\max }^{0}$ は他の歩行者 が存在しないときの上限値とする.

(2) 停止・回避行動のモード

歩行者は認識領域内にいる最も影響を及ぼす他の歩行 者との関係により，いくつかのモードを選択すると考え られている 17$]$. ここでは他の歩行者から受ける影響を つぎのように定め, 最も影響を及ぼす他の歩行者を選ぶ ことにする.

$$
E\left(d_{i j}, \theta_{i j}\right)=\frac{\cos \theta_{i j}}{d_{i j}}
$$




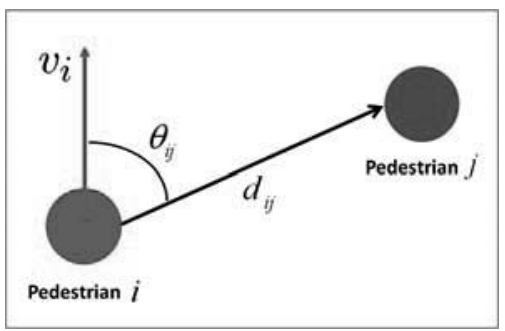

Fig. 4 Evaluation of a dominant pedestrian

ここで, $d_{i j}$ は注目している他の歩行者との距離， $\theta_{i j}$ は進行方向との偏角である. よって (17) 式を用いると， 進行方向に近い歩行者，また近くにいる歩行者が優先さ れて選ばれる.

つぎに Fig. 5 のような領域を定め, 停止・回避のモ一 ドを導入する. ここで, 歩行者 $i$ は注目している歩行者で あり，歩行者 $j$ は最も影響を与える歩行者である. 乥し て, 歩行者 $i, j$ の相対速度により半径 $R=k_{R} \cdot\left|v_{j}-v_{i}\right|$ の円 (停止領域) と一辺が $L=k_{L} \cdot\left|v_{j}-v_{i}\right|$ の長方形 (回 避領域) が描かれている.ここでの $k_{L}, k_{R}$ は相対速度に 対する比例係数であり, $k_{L}=0.7, k_{R}=0.2$ と定めた. 光 して, 注目している歩行者 $i$ が存在している位置によっ て，つぎのようなモードを定める.

(i) 停止行動: Fig. 6 のように歩行者 $i$ が円内に入った とき歩行者は停止する. 乥して本モードでは，モデ ル予測制御の計算を 1 ステップ分行わない.

(ii) 回避行動: Fig. 7 のように歩行者 $i$ が円外かつ長方 形内の領域に存在するとき，回避行動をとるとする. そして Fig. 7 の領域 (斜線部) を一時的に禁止領域 として定め，この制約条件を(11) 式に加えモデル 予測制御問題を解くことにより, 歩行者 $i$ が回避す る動きを表現する.

(3) 追従行動のモード

先行する歩行者がほぼ同じ方向に歩いているとき，後 ろを歩く歩行者は追従し，他の歩行者との衝突を回避す る傾向がある [17]. 乥こで，歩行者が停止・回避領域外 に存在するとき，(2) で定めた最も影響を与える歩行者 $j$ との関係を以下のように判定する (Fig. 8).

- 目標点との方向と, 歩行者 $j$ の方向の差が $\pi / 9[\mathrm{rad}]=$ 20[deg] 以内である.

- $v_{i}, v_{j}$ のなす角が $\pi / 9[\mathrm{rad}]=20[\mathrm{deg}]$ 以内である.

- $v_{i}, v_{j}$ の速度差が $v_{i}$ の $50 \%$ 以内である.

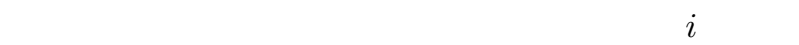
ての目標点を歩行者 $j$ に変更し，モデル予測制御問題を 解き追従行動を表現することにする.

(注意) Fig. 7 の回避行動のモードに基づいて, 歩行可 能領域はつぎの手順から求められる.

1) 歩行者 $i$ と他の歩行者 $j$ の位置を, 弚れ光れ $p_{i}=$ $\left(x_{i}, y_{i}\right), p_{j}=\left(x_{j}, y_{j}\right)$ と表し, 直角三角形の条件か ら $p_{i}$ を通る直線と $p_{j}$ を中心とする半径 $R$ の円

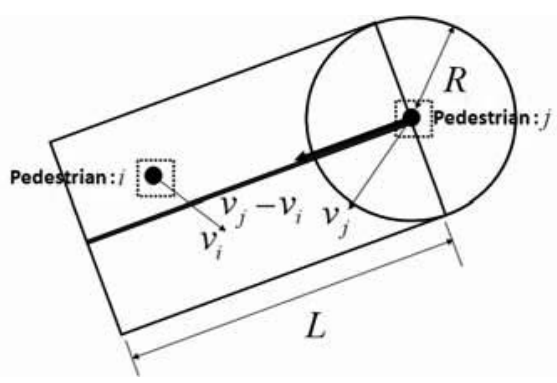

Fig. 5 Stopping and avoidance region

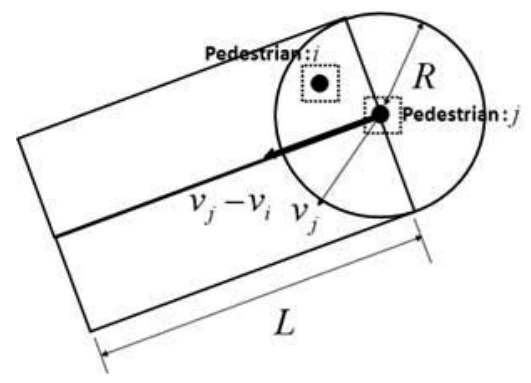

Fig. 6 Stopping mode

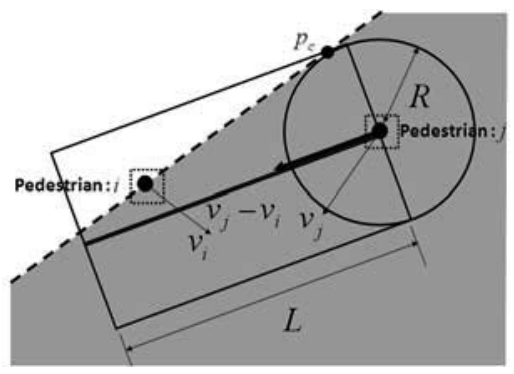

Fig. 7 Avoidance mode

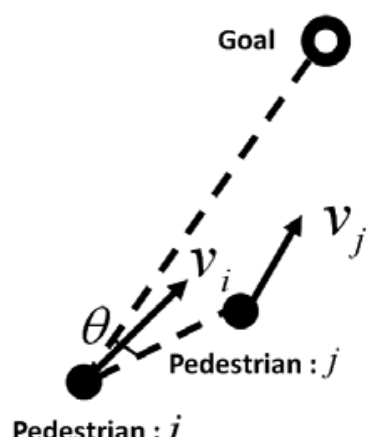

Pedestrian : $i$

Fig. 8 Following mode

の接点を求める (接点は二つ求められる).

2）回避領域の長方形を Fig. 7 のように中心線で二分 したとき，歩行者 $i$ と同じ領域に属する接点を採 用する (位置ベクトルを $p_{c}$ とする，Fig. 7).

$3)$ 歩行可能領域の座標を $p=(x, y)$ とすると, ベク トル $p-p_{i}$ と $p_{c}-p_{j}$ のなす角は $90[\mathrm{deg}]$ 以内で あり，制約条件は内積から

$$
\left(p_{c}-p_{j}\right)^{T}\left(p-p_{i}\right) \geq 0
$$

と求められる. 
Table 1 Parameters of flow coefficient

\begin{tabular}{|c|l|}
\hline パラメータ & \multicolumn{1}{|c|}{ 説 明 } \\
\hline$N_{\text {eff }}[$ 人 $/ \mathrm{s} \cdot \mathrm{m}]$ & 有効流動係数 \\
\hline$p\left[\right.$ 人 $\left./ \mathrm{m}^{2}\right]$ & 歩行者の密度 \\
\hline$A_{\text {area }}\left[\mathrm{m}^{2}\right]$ & 当該居室などの床面積 \\
\hline$t_{\text {queue }}[\mathrm{s}]$ & 出口の通過に要する時間 \\
\hline$B_{\text {room }}[\mathrm{m}]$ & 有効出口幅 \\
\hline
\end{tabular}

以上の相互作用を新たに (15) 式の制約に加え，群集 内における各歩行者の行動を表すことにする.

$$
\min _{U} J, U:=\{u(t \mid t), u(t+1 \mid t), \ldots, u(t+N-1 \mid t)\}
$$

$$
\text { subj.to }\left[\begin{array}{l}
\text { 状態方程式 }(5) \\
\text { 位置・速度の制約 }(8), \quad k=0, \ldots, N-1 \\
\text { 衝突回避条件 }(13) \\
\text { 群集内での相互作用 }
\end{array}\right.
$$

そして群集のシミュレーションにおいては, モデル予測 制御問題を解く歩行者の順番を決めておき，弚の順番に 従って, 各歩行者の状態を 1 サンプル時間ごとに更新し ていく.

\section{3. シミュレーションと考察}

2 節で定めたモデルに基づき，群集が部屋から退出す るシミュレーションを行い, 流動係数の視点から出口付 近の障害物の効果について考察する. 流動係数とは単位 時間 $(1[\mathrm{~s}])$ あたりに単位幅 $(1[\mathrm{~m}])$ の出口を通過する人 数であり，つぎのように定められる (Table 1 参照)[18].

$$
N_{\text {eff }}=\frac{p \cdot A_{\text {area }}}{t_{\text {queue }} \cdot B_{\text {room }}}
$$

また，各パラメータは Tables 2, 3 のように定め， ここでは最大歩行速度 $v_{\max }=1.2[\mathrm{~m} / \mathrm{s}]$, サンプル時間 $h=0.1[\mathrm{~s}]$ ，予測ホライズン $N=5$ とした。 これは混雑 時，歩行者が $0.4 〜 0.6[\mathrm{~m}]$ の間隔で障害物を回避し，経 路を変更することに対応させたものである. 一方, 歩行 者間で回避，追従の行動を表現するアルゴリズムは 2.2 節で記述したとおり，認識領域によって制約，目標点の 変更が定められている.このことより本手法では，近い 距離の回避動作はモデル予測制御により考慮し，遠い距 離での経路計画は回避，追従のモードによって考慮して いる.

(a),(b),(c) の設定において，群集挙動のシミュレー ションを行い, 退出に要する時間と流動係数の関係を調 ベる.

(a) 障害物を配置しない場合 (Fig. 9(a))

(b) 障害物を出口正面から $3[\mathrm{~m}]$, 上方に $2.5[\mathrm{~m}]$ ずら して非対称に配置した場合 (Fig. 9(b))

(c) 障害物を出口正面から $3[\mathrm{~m}]$ に対称に配置した場合 (Fig. 9(c))

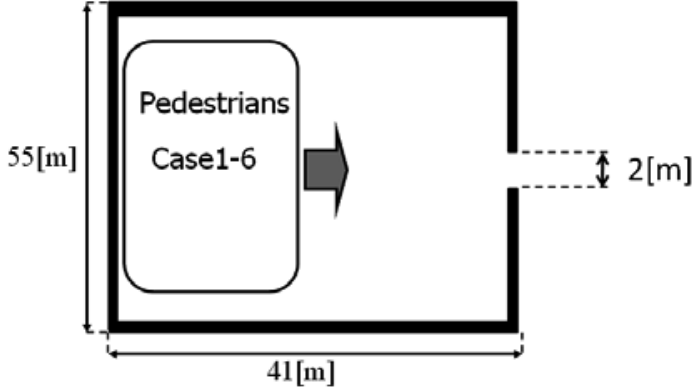

Case(a): an obstacle is not placed

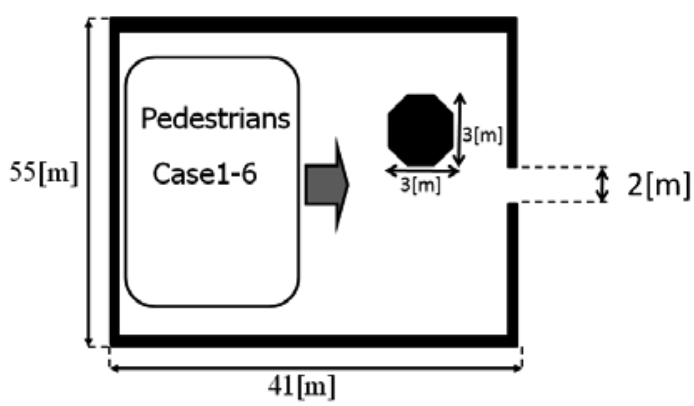

Case(b): an obstacle is placed asymmetrically in front of the exit

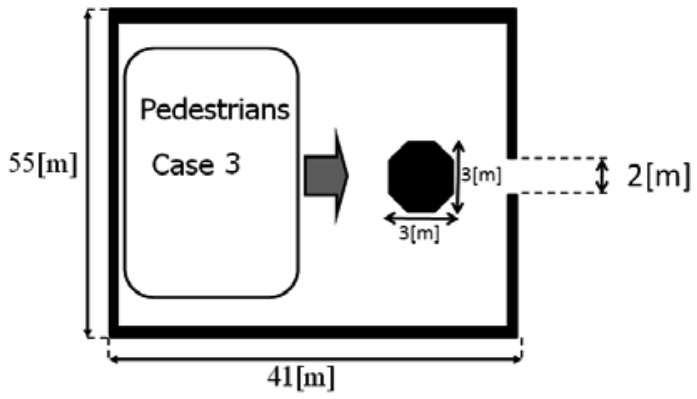

Case(c): an obstacle is placed in front of the exit

Fig. 9 Floor layout

ここでは , 評価関数 $(15)$ 式における目標点 $s_{f}$ は出口 の位置，重みは $Q=10^{-6}, R=1$ と定めた ${ }^{1}$. Fig. $9(\mathrm{~b})$ の障害物を非対称に配置したとき，退出時間が短縮され る現象は, 文献 [5,7]で報告され，この現象の再現がモ デルの有用性を検証する一つの評価基準と位置付けられ ている. また，歩行者の最大速度は，文献 [19] を参考に Table 3 のように定めた.

シミュレーション結果は Figs. 10-15 のように求めら れ，弚れ光れの群集と退出時間の関係は Table 4 のよ うにまとめられる.いずれの場合も障害物を配置したほ うが退出時間を若干短縮できることが確認できる. しか しながら Case 5,6 のように速度が遅い歩行者が多い場 合，短縮される時間がわずかである. これは速い歩行者

${ }^{1}$ 評価関数の重み行列 $Q, R$ は文献 [21] で検討され，歩 行者の対向・追い越しの現象が再現されることが確認 されている. また，これらの準備的な検証において， フィールドデータとほぼ同じスケールの軌跡が再現さ れたことから，本シミュレーションに導入した. 
Table 2 Parameters of simulation model

\begin{tabular}{|c|c|l|}
\hline パラメータ & 値 & \multicolumn{1}{|c|}{ 説 明 } \\
\hline$m[\mathrm{~kg}]$ & 60 & 歩行者の質量 \\
\hline$\mu[\mathrm{Ns} / \mathrm{m}]$ & 20 & $\begin{array}{l}\text { 歩行者の速度変化の緩慢さを } \\
\text { 表す抵抗係数 }\end{array}$ \\
\hline$h[\mathrm{~s}]$ & 0.1 & サンプル時間 \\
\hline$N$ & 5 & 予測ホライズン \\
\hline$D[\mathrm{~m}]$ & 0.4 & 歩行者の大きさ (Fig. 2) \\
\hline$l[\mathrm{~m}]$ & 3.0 & 認識領域の半径 (Fig. 3) \\
\hline$\theta[\mathrm{rad}]$ & $\pi / 3$ & 進行方向との偏角 (Fig. 3) \\
\hline$d_{i j}[\mathrm{~m}]$ & & 他の歩行者との距離 (Fig. 4) \\
\hline$\theta_{i j}[\mathrm{rad}]$ & & $\begin{array}{l}\text { 他の歩行者と進行方向の偏角 } \\
\text { (Fig. 4) }\end{array}$ \\
\hline$k_{L}$ & 0.7 & $\begin{array}{l}\text { 停止・回避領域を定める比例 } \\
\text { 定数 (Fig. 5) }\end{array}$ \\
\hline$k_{R}$ & 0.2 & $\begin{array}{l}\text { 停止・回避領域を定める比例 } \\
\text { 定数 (Fig. 5) }\end{array}$ \\
\hline
\end{tabular}

Table 3 Dynamics of pedestrian flow

\begin{tabular}{|c|l|}
\hline Case & \multicolumn{1}{|c|}{ 説 明 } \\
\hline 1 & $\begin{array}{l}\text { 最大歩行速度を } v_{\max }=0.8[\mathrm{~m} / \mathrm{s}] \text { と定めた } \\
\text { 歩行者 } 150 \text { 人 }\end{array}$ \\
\hline 2 & $v_{\max }=1.2[\mathrm{~m} / \mathrm{s}]$ とした歩行者 150 人 \\
\hline 3 & $\begin{array}{l}v_{\max }=1.2[\mathrm{~m} / \mathrm{s}] \text { とした歩行者 } 120 \text { 人 } \\
\text { および } 0.8[\mathrm{~m} / \mathrm{s}] \text { とした歩行者 } 30 \text { 人 }\end{array}$ \\
\hline 4 & $\begin{array}{l}v_{\max }=1.2[\mathrm{~m} / \mathrm{s}] \text { とした歩行者 } 90 \text { 人 } \\
\text { および } 0.8[\mathrm{~m} / \mathrm{s}] \text { とした歩行者 } 60 \text { 人 }\end{array}$ \\
\hline 5 & $\begin{array}{l}v_{\max }=1.2[\mathrm{~m} / \mathrm{s}] \text { とした歩行者 } 60 \text { 人 } \\
\text { および } 0.8[\mathrm{~m} / \mathrm{s}] \text { とした歩行者 } 90 \text { 人 }\end{array}$ \\
\hline 6 & $\begin{array}{l}v_{\max }=1.2[\mathrm{~m} / \mathrm{s}] \text { とした歩行者 } 30 \text { 人 } \\
\text { および } 0.8[\mathrm{~m} / \mathrm{s}] \text { とした歩行者 } 120 \text { 人 }\end{array}$ \\
\hline
\end{tabular}

Table 4 Evaluated evacuation times

\begin{tabular}{|c|c|c|}
\hline Case & Floor layout & Evacuation time [s] \\
\hline \multirow{2}{*}{1} & (a) & 79.0 \\
\cline { 2 - 3 } & (b) & 78.2 \\
\hline \multirow{2}{*}{2} & $(\mathrm{a})$ & 55.4 \\
\cline { 2 - 3 } & (b) & 54.6 \\
\hline \multirow{2}{*}{3} & (a) & 58.9 \\
\cline { 2 - 3 } & (b) & 58.0 \\
\hline \multirow{2}{*}{4} & (a) & 64.3 \\
\cline { 2 - 3 } & (b) & 63.7 \\
\hline \multirow{2}{*}{5} & (a) & 67.8 \\
\cline { 2 - 3 } & (b) & 67.5 \\
\hline \multirow{2}{*}{6} & (a) & 71.6 \\
\cline { 2 - 3 } & (b) & 71.3 \\
\hline
\end{tabular}

が追い抜いていく行動が多発し，退出時間を短縮させる 効果が十分に現れなかったためと考えられる.また，典 型的な混杂隹の樣子は , Figs. 10-13 のようにまとめられ る. ここで Figs. 10, 11 は Case 3(a),(b) に対応するシ ミュレーション結果であり, Figs. 12, 13 は, 歩行者を 中心に直径 $1[\mathrm{~m}]$ の円を書き込んだものである.

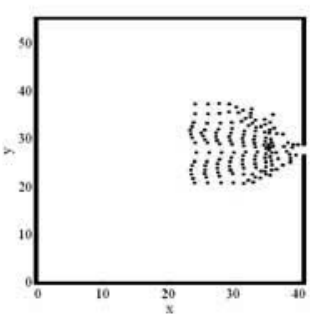

$t=20[\mathrm{~s}]$

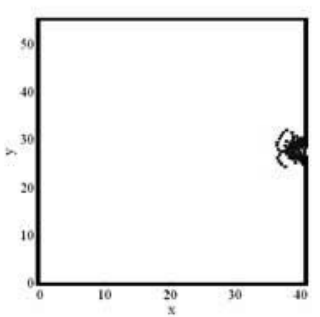

$t=40[\mathrm{~s}]$

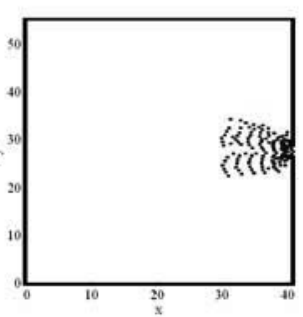

$t=30[\mathrm{~s}]$

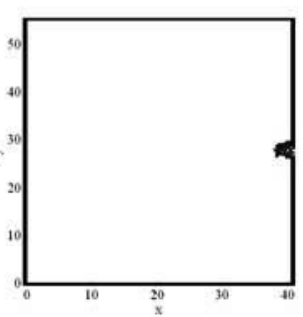

$t=50[\mathrm{~s}]$
Fig. 10 Simulation result: Case 3(a)

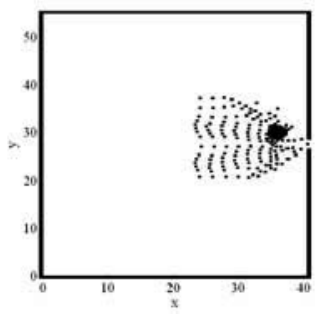

$t=20[\mathrm{~s}]$

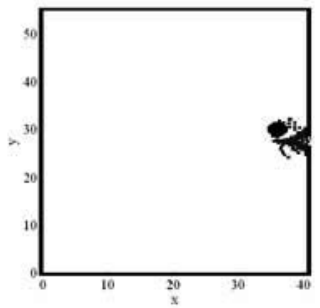

$t=40[\mathrm{~s}]$

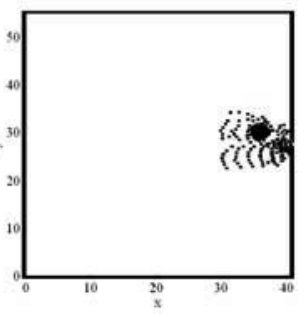

$t=30[\mathrm{~s}]$

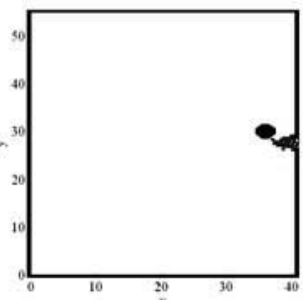

$t=50[\mathrm{~s}]$
Fig. 11 Simulation result: Case 3(b)

シミュレーション結果から以下のことが確認できる.

(1) 障害物がない場合では, 大きなアーチ状の混杂隹が 形成され，結果的に退出に要する時間が長くなる.

(2) 障害物を非対称に配置した場合は, 歩行者の経路 が二分されるため, アーチ状の混杂隹の発生が遅れ， 比較的高い流動性が維持できる可能性がある.

また Case 3(a),(b) における流動係数の時間変化は Figs. 14, 15 のようにまとめられ, 以下のことが確認で きる.

(3) 障害物を非対称に配置した場合 (Fig. 15) は，障害 物がない場合 (Fig. 14) に比べて流動係数の立ち上 がりが緩やかである.このことより歩行者が出口 に殺到しにくく，出口でのアーチ状の混杂倠が形成 


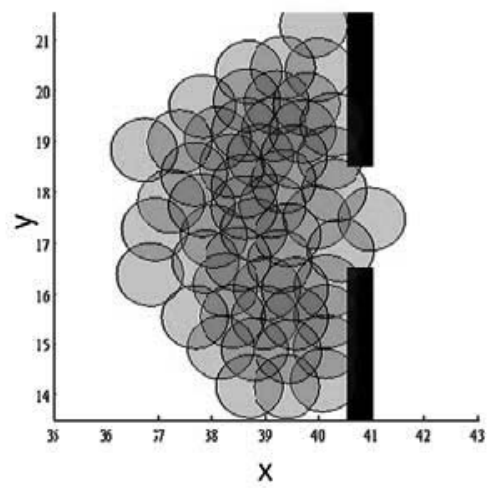

Fig. 12 Congestion around the exit: Case 3(a)

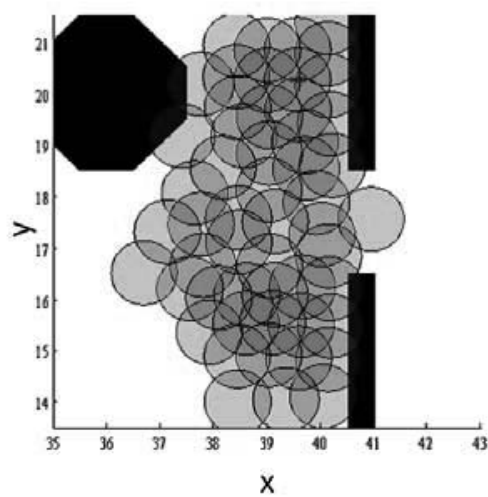

Fig. 13 Congestion around the exit: Case 3(b)

される時間を若干遅らせることができる.

（4）障害物がない場合 (Fig. 14)，アーチが形成されて は部分的に解消される現象か繰り返されるため，流 動係数が脈動する傾向がある.

さらに障害物を対称に配置した場合 (Case 3(c))，流動 係数の時間変化は Fig. 16 のようになり，以下のことが 確認される.

（5）障害物を対称に配置した場合 (Fig. 16)，流動係数 が脈動する樣子はやや抑えられるが，退出時間は 短縮されない．これは，出口までの到達時間に差 がつかず，混雑が分散されないためと考えられる. また，立ち上がりの樣子は非対称に配置したとき (Fig. 15) と同樣であるが, 定常時には脈動が生 じる.

Figs. 14-16 における退出開始時から終了時までの流 動係数の平均値は，乥れ艺れ $1.68,1.73,1.69[$ 人 $/(\mathrm{s} \cdot \mathrm{m})]$ であった. 同一のレイアウトにおいて，文献 [18] では流 動係数が $1.5[$ 人 $/(\mathrm{s} \cdot \mathrm{m})]$ と示されており，ほほ対応する 流動係数が再現されている.

\section{4. おわりに}

本論文では，MLD システム表現に基づいた群集挙動 のモデルを提案した. 弚して，1) 歩行者を質点の力学

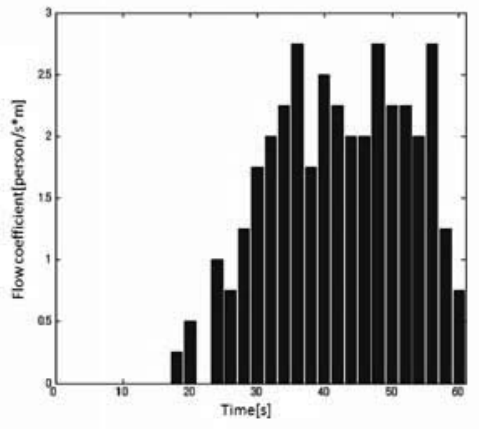

Fig. 14 Flow coefficient: Case 3(a)

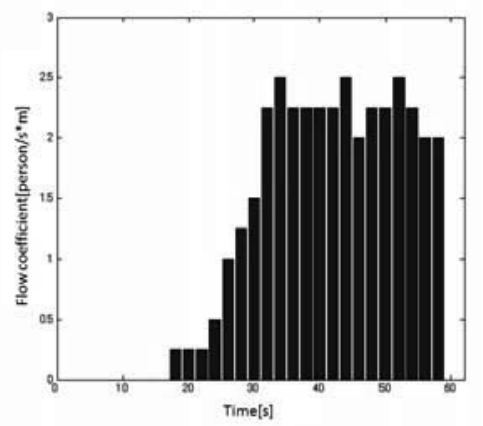

Fig. 15 Flow coefficient: Case 3(b)

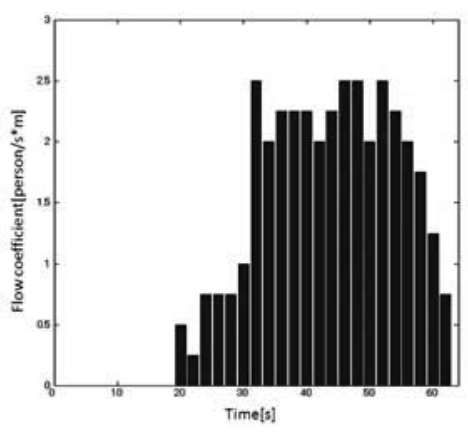

Fig. 16 Flow coefficient: Case 3(c)

モデルと考え, 停止・回避・追従のモードを導入するこ と $[16,17], 2)$ 歩行者の自律的な歩行行動をモデル予測 制御制御により表現すること，により退出行動のシミュ レーションを行い，これらの前提から，1) アーチ状の混 杂隹が形成され，妥当な流動係数が再現されること [18] ,

2) 群集モデルの評価基準とされる障害物を配置したシ ミュレーションにおいて, 退出時間が短縮される現象が 再現されること $[5,7]$ を確認した.

今後, フィールドデータに基づいて力学モデルの細部 の検証を進め, また複数の領域を結合させた一般的なシ ミュレーションを通じて手法の有用性を検討する予定で ある。

参 考文 献

[1] 堀内, 室崎, 田中: 大震火災時の群集避難計画に関する 研究 谷の 1 ; 日本建築学会大会学術講演梗概集, Vol. 48, 
pp. 1241-1242 (1973)

[2] 小林, 堀内: オフィスビルの火災時の人間の行動分析 乥 の 1 ; 日本建築学会論文報告集, Vol. 280, pp. 137-142 (1979)

[3] 小林, 堀内: オフィスビルの火災時の人間の行動分析 光 の 2; 日本建築学会論文報告集, Vol. 284, pp. 119-125 (1979)

[4] 戶沼, 根岸: 歩行空間における人間行動; 日本建築学会大 会学術講演梗概集, Vol. 58, pp. 2127-2128 (1983)

[5] D. Helbing, L. Buzna, A. Johansson and T. Werner: Self-organized pedestrian crowd dynamics: experiments, simulations, and design solutions; Transportation Science, Vol. 39, pp. 1-24 (2005)

[6] D. Helbing and P. Molnar: Social force model for pedestrian dynamics; Phys. Rev. E 51, pp. 4282-4286 (1995)

[7] D. Helbing, I. Farkas and T. Vicsek: Simulating dynamical features of escape panic; Nature (London), Vol. 407, pp. 487-490 (2000)

[8] D. Helbing, I. J. Farkas, P. Molnar and T. Vicsek: Simulation of Pedestrian Crowds in Normal and Evacuation Situations, Springer, pp. 21-58 (2002)

[9] O. Khatib: Real-time obstacle avoidance for manipulators and mobile robots; International Journal of Robotics Research, Vol. 5, No. 1 (1986)

[10] 浅田，國吉: ロボットインテリジェンス, 岩波書店 (2006)

[11] A. Kirchner, K. Nishinari and A. Schadschneider: Friction effects and clogging in a cellular automaton model for pedestrian dynamics; Phys. Rev. E 67, 056122 (2003)

[12] 柳沢, 西成: クラスター近似による出口を通過する人 の流量の式の導入; 日本応用数理学会論文誌, Vol. 17, pp. 277-290 (2007)

[13] A. Bemporad and M. Morari: Control of systems integrating logic, dynamics, and constraints; Automatica, Vol. 35, pp. 407-427 (1999)

[14] A. Bemporad, D. Mignone and M. Morari: Moving horizon estimation for hybrid systems and fault detection; Proc. of the American Control Conference, Vol. 4, pp. 2471-2475 (1999)

[15] M. Mukai, J. Murata, T. Kawabe, H. Nishira, Y. Takagi and Y. Deguchi: Optimal path generation for automotive collision avoidance using mixed integer programming; SICE Journal of Control, Measurement, and System Integration, Vol. 1, No. 3, pp. 222-
$226(2008)$

[16] 岡崎, 松下: 建築空間における歩行のためのシミュレー ションモデルの研究 光の 1 ; 日本建築学会計画系論文報 告集, Vol. 283, pp. 111-117 (1979)

[17] 岡崎, 松下: 建築空間における歩行のためのシミュレー ションモデルの研究 その 2 ; 日本建築学会計画系論文報 告集, Vol. 284, pp. 101-108 (1979)

[18] 国土交通省住宅局建築指導課, 国土交通省建築研究所, 日本建築主事会議, 財団法人日本建築センター: 2001 年 度版避難安全検証法の解説及ひ計算例と光の解説, 井上 書院 (2001)

[19] 梶原, 山田: 歩行速度の決定要因に関する分析的研究; 日 本建築学会学術講演梗概集, pp. 951-952 (2007)

[20] G. Tanaka and A. Kojima: A modeling of crowd behavior based on model predictive control; Proc. of SICE-ICCAS International Joint Conference 2006, CD-ROM, pp. 5120-5124 (2006)

[21] A. Kojima and G. Tanaka: A modeling of pedestrian dynamics in crowd based on MLD system approach; Proc. of 17th International Symposium on Mathematical Theory of Network and Systems (MTNS2006), pp. 634-637 (2006)

\section{著者 略 歴}

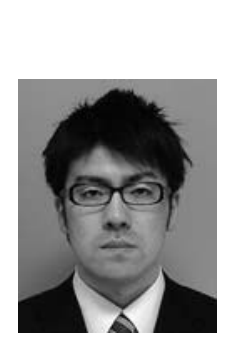
と徹 (学生会員) 1984 年 9 月 11 日生. 2008 年東京都立 科学技術大学工学部電子システム工学科 卒業, 2010 年首都大学東京大学院システ ムデザイン研究科ヒューマンメカトロニク スシステム学域 博士前期課程修了. 現在 , 本田技研工業 (株) に勤務 . ハイブリッド システム表現を用いた群集挙動のモデリングの研究に従事 .

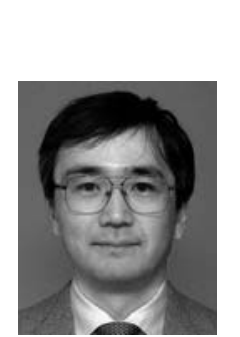

孛 正会員)

1991 年早稲田大学大学院理工学研究科 博士後期課程修了 . 同年, 東京都立科学技 術大学講師, 1997 年同助教授 , 2004 年首 都大学東京教授となり,現在に至る.20002001 年スイス連邦工科大学 (ETH) 自動制 御研究所 客員研究員. モデル予測制御と 弚の応用，ロバスト制御，むだ時間系をはじめとする分布系 の制御などの研究に従事. 工学博士. IEEE, 計測自動制御 学会, 日本鉄鋼協会, 電気学会などの会員. 